\title{
IMPLEMENTASI KEBIJAKAN BADAN PENYELENGGARA JAMINAN SOSIAL KESEHATAN DI PUSKESMAS KOPO KECAMATAN KUTAWARINGIN KABUPATEN BANDUNG
}

\author{
Enceng Sakti Alamsyah*1, Ratna Meisa Dai ${ }^{2}$, Deasy Silvya Sari ${ }^{3}$ \\ ${ }^{1}$ Program Pascasarjana Kebijakan Publik, FISIP Unpad \\ ${ }^{2}$ Departemen Administrasi Bisnis, FISIP Unpad \\ ${ }^{3}$ Departemen Hubungan Internasional, FISIP Unpad \\ encengsakti@gmail.com
}

\begin{abstract}
ABSTRAK
Keberadaan kebijakan tentang BPJS Kesehatan, idealnya, membawa perubahan positif untuk kesehatan masyarakat. Bagi Pusat Kesehatan Masyarakat (Puskesmas) sebagai fasilitas kesehatan tingkat pertama, implementasi Kebijakan tentang BPJS merupakan hal yang urgen. Artikel ini bertujuan menelaah implementasi kebijakan BPJS Kesehatan di Pusat Kesehatan Masyarakat Kopo, Kecamatan Kutawaringin Kabupaten Bandung. Teori yang digunakan adalah model Van Metter dan Van Horn. Penelitian ini menggunakan pendekatan kualitatif dengan metode deskriptif. Pengumpulan data meliputi studi dokumentasi, observasi, dan wawancara. Teknik analisis data menggunakan reduksi data, penyajian data, verifikasi data, dan penarikan kesimpulan.

Penulis menemukan bahwa Puskesmas Kopo telah menjalankan implementasi kebijakan Badan Penyelenggara Jaminan Sosial (BPJS) Kesehatan. Puskesmas Kopo memiliki tenaga Kesehatan yang memahami tujuan kebijakan BPJS Kesehatan sehingga mereka patuh terhadap klausa-klausa kebijakan yang ada. Mereka juga mumpuni menangani kasus-kasus yang menjadi tanggung jawab fasilitas kesehatan tingkat I dengan kecenderungan sikap yang antusias dalam mengimplementasikan kebijakan BPJS Kesehatan. Puskesmas Kopo melakukan hubungan yang intens dengan Kantor BPJS dalam implementasi kebijakan BPJS. Dari aspek lingkungan ekonomi, sosial, dan politik, Masyarakat di wilayah kerja Puskesmas Kopo memiliki tingkat kepeduliaan terhadap program BPJS Kesehatan. kepedulian ini muncul dari kesadaran dan realita bahwa program BPJS Kesehatan mampu meningkatkan taraf kesehatan masyarakat tanpa membedakan dari jenis-jenis profesi. Meski demikian, keberadaan pimpinan yang mampu mengontrol koordinasi antar unit sangat diperlukan karena implementasi kebijakan ini melibatkan banyak unit serta kendala-kendala teknis di lapangan kerap terjadi.

Kata kunci: Implementasi Kebijakan, BPJS Kesehatan, Pusat Kesehatan Masyarakat
\end{abstract}

\begin{abstract}
Ideally, the existence of a policy on BPJS Kesehatan will bring positive changes to public health. For the Community Health Center (Puskesmas) as a first-level health facility, the implementation of the BPJS Policy is urgent. This article aims to examine the implementation of the BPJS Health policy at the Kopo Community Health Center, Kutawaringin District, Bandung Regency. The theory used is the Van Metter and Van Horn model. This study uses a qualitative approach with descriptive methods. Data collection includes documentation study, observation, and interviews.

The author found that the Kopo Health Center had implemented the Health Social Security Administration (BPJS) policy. Kopo Puskesmas have health personnel who understand the objectives of BPJS Health policies so that they comply with existing policy clauses. They are also capable of handling cases that are the responsibility of level I health facilities with a tendency to be enthusiastic in implementing BPJS Health policies. The Kopo Puskesmas maintains an intense relationship with the BPJS office in implementing BPJS policies. From the aspects of the economic, social and political environment, the people in the working area of the Kopo Health Center have a level of concern for the BPJS Health program. This concern arises from the awareness and reality that the BPJS Kesehatan program is able to improve the level of public health regardless of the
\end{abstract}


types of professions. However, the existence of a leader who is able to control coordination between units is very much needed because the implementation of this policy involves many units and technical problems in the field often occur.

Keywords: Policy Implementation, BPJS Health, Community Health Center

\section{PENDAHULUAN}

Kesehatan adalah hak masyarakat, dan hak masyarakat harus dikelola oleh pemerintah sesuai dengan ketentuan Pasal 28H ayat 1 UUD 1945 yaitu, "Setiap orang berhak menikmati jasmani dan rohani. kesehatan, tempat tinggal, dan kehidupan yang baik dan sehat. Lingkungan dan hak atas pelayanan kesehatan "dan Pasal 34 ayat 3," Negara bertanggung jawab untuk menyediakan fasilitas pelayanan kesehatan yang memadai dan fasilitas pelayanan umum.

Upaya pemerintah Indonesia untuk menangani masalah kesehatan masyarakat adalah menerapkan jaminan perlindungan kesehatan supaya semua masyarakat mendapat manfaat pemeliharaan kesehatan. Program yang diselenggarakan pemerintah adalah program Badan Penyelenggara Jaminan Sosial Kesehatan.

BPJS dalam UU 40 Tahun 2004 Tentang Sistem Jaminan Sosial Nasional adalah "trasformasi dari badan penyelenggara jaminan sosial yang sekarang telah berjalan dan dimungkinkan untuk membentuk badan penyelenggara baru sesuai dengan dinamika perkembangnan jaminan sosial”. (Putri, 2014:7) Program tersebut terdiri atas jenis nonPBI (non-Penerima Bantuan Iuran) bagi masyarakat yang mampu dan PBI (Penerima Bantuan Iuran) bagi masyarakat yang tidak mampu. Namun sekarang Penerima Bantuan Iuran sesuai Data Terpadu Kesejahteraan Sosial. Apabila Data Terpadu Kesejahteraan Sosial (DTKS) tidak diperbaharui maka dapat menyebabkan kartu BPJS Kesehatan gratis nonaktif hingga kemudian harus datang ke kantor BPJS setempat untuk mengaktifkannya kembali namun terjadi perubahan status yang tadinya gratis menjadi berbayar. Karena jika status kepesertaan aktif pemerintah akan memberikan bantuan, namun jika tidak aktif maka pemerintah tidak akan membayar.

Pada BPJS non-PBI terdapat kelas 1, kelas 2 dan kelas 3 sesuai tingkat layanan kesehatan dan tarif yang harus dibayar setiap bulan. Dengan membayar iuran sesuai tarif tentu masyarakat berhak menerima layanan kesehatan berikut fasilitas sesuai kelasnya. Diantaranya layanan rawat jalan, rawat inap, persalinan, berikut alat bantuan kesehatan jika diperlukan. Namun demikian, BPJS Kesehatan non-PBI memberlakukan denda apabila masyarakat yang sudah menjadi peserta terlambat membayar iuran.

Adanya BPJS Kesehatan dengan program Jaminan Kesehatan Nasional-Kartu Indonesia Sehat selayaknya membawa perubahan positif untuk bidang kesehatan Nasional. Diantaranya terjadi peningkatan kualitas pelayanan ditunjang sarana dan prasarananya seperti pada Puskesmas sehingga Puskesmas tidak dipandang sebelah mata karena saat ini sebagai fasilitas kesehatan tingkat pertama (FKTP) yang paling banyak dipilih oleh peserta JKN-KIS. Namun pada implementasinya, program tersebut menemui banyak masalah, termasuk pada Puskesmas Kopo Kecamatan Kutawaringin Kabupaten Bandung.

Berdasarkan hasil observasi awal, ditemukan adanya fenomena yang terjadi di Puskesmas Kopo Kecamatan Kutawaringin Kabupaten Bandung, yaitu jumlah kepesertaan BPJS setiap tahunnya menurun, dari Tahun 2017 ke tahun 2018 turun 10.054 peserta, dari Tahun 2018 ke tahun 2019 turun 77.733 peserta, dan dari ari Tahun 2019 ke pertengahan tahun 2020 turun 220.922 peserta. Diduga penyebab terjadinya fenomena tersebut karena kurangnya kepedulian dan antusiasme masyarakat Kutawaringin dengan alasan naiknya tarif iuran bulanan BPJS tidak sebanding dengan layanan yang diterima sehingga merasa dirugikan. Selain itu karena masih banyaknya peserta yang tidak disiplin membayar iuran setiap bulan sehingga mengakibatkan status kepesertaan menjadi tidak aktif.

Hal tersebut dapat dilihat pada data kapitasi di Puskesmas Kopo Kecamatan Kecamatan Kutawaringin Kabupaten Bandung pada Tahun 2018 sampai pertengahan Tahun 2020, terdapat penurunan nilai pembayaran 
yang cukup signifikan, penurunan pembayaran iuran BPJS Kesehatan berdasarkan jumlah peserta yang terjadi dari Tahun 2018 ke Tahun 2019 sebesar Rp 441.346.600,-, dari Tahun 2019 ke pertengahan Tahun 2020 terjadi penurunan sebesar Rp 1.156.988.300,-.

Penurunan angka kapitasi di Pusksesmas Kopo tersebut di atas didukung oleh penurunan data contact rate peserta BPJS Kesehatan dalam dua setengah tahun terakhir, nilai angka penurunannya adalah dari Tahun 2018 ke Tahun 2019 sebesar 8.448, dan dari Tahun 2019 ke Tahun 2020 sebesar 10.330.

Dalam mengoptimalkan pelayanan kepada masyarakat dengan lebih spesifik Badan Penyelenggara Jaminan Sosial Kesehatan juga mengelurakan Program Pengelolaan Penyakit Kronis (Prolanis). Data cakupan Prolanis di Puskesmas Kopo Kecamatan Kutawaringin Kabupaten Bandung, seperti halnya data peserta lainnya menunjukan angka penurunan, dari Tahun 2018 ke tahun 2019 turun 5 Peserta Prolanis, dan dari Tahun 2019 ke pertengahan tahun 2020 turun 773 Peserta Prolanis.

Perbandingan jumlah peserta PBI dan Non-PBI di Puskesmas Kopo adalah: jumlah peserta PBI sebanyak 23.273 orang, sedangkan jumlah peserta non-PBI sebanyak 2.515, sehingga jumlah keseluruhan peserta BPJS Kesehatan di Faskes PKM Kopo sebanyak 25.788 orang. Artinya jumlah peserta BPJS Kesehatan PBI dilihat dari sisi persentase dibanding peserta No-PBI yaitu: 90,25\% banding 9,75\%.

Berbagai fenomena tersebut terjadi karena sebagian masyarakat merasa adanya perbedaan perlakuan antara pengguna dan non pengguna BPJS Kesehatan sehingga membuat pengguna BPJS merasa dibeda-bedakan dalam pelayanan karena petugas kesehatan yang bersikap kurang ramah dalam melayani pasien. Selanjutnya, karena masih adanya tenaga atau petugas kesehatan yang bersikap kurang profesional dalam menjalankan tugasnya, seperti catatan medis yang tidak lengkap dan kurang mampu merespon pertanyaan yang berkaitan dengan tindakan medis yang dilakukan. Selain itu karena sosialisasi yang kurang maksimal, fasilitas kesehatan yang kurang memadai dan jumlah tenaga medis yang terbatas serta kartu BPJS Kesehatan gratis menjadi nonaktif karena tidak adanya pembaharuan Data Terpadu Kesejahteraan Sosial (DTKS).

Masalah lain yang muncul adalah sesuai dengan temuan Badan Pengawasan Keuangan dan Pembangunan (BPKP), yaitu adanya sisa lebih pembiayaan anggaran (SILPA) dan dananya mengendap di Kas Daerah dan Dinas Kesehatan. Besaran pembayaran per bulan yang dibayar di muka kepada Fasilitas Kesehatan Tingkat Pertama (FTKP) berdasarkan jumlah peserta yang terdaftar tanpa memperhitungkan jenis dan jumlah pelayanan kesehatan yang diberikan yang tidak terpakai dapat menyebabkan dua masalah yaitu kesalahan pembiayaan dan pelayanan yang kurang optimal kepada peserta. Untuk memanfaatkan SILPA tersebut pihak Puskesmas Kopo harus menunggu putusan DPRD Kabupaten Bandung. Namun dalam jangka waktu setelah tiga bulan atau bahkan bisa sampai satu tahun putusan tersebut baru keluar sehingga bisa berakibat pada terhambatnya pelayanan terhadap peserta, diantaranya fasilitas layanan menjadi berkurang karena pihak puskesmas tidak bisa membeli obat dan upah tenaga honor di Puskesmas jadi terlambat dibayar.

Cita-cita program BPJS Kesehatan adalah supaya masyarakat bisa terlayani dengan baik di Puskesmas karena lebih mudah dijangkau. Namun, berdasarkan aspek mutu sarana pelayanan di Puskesmas tidak siap menerima pasien BPJS Kesehatan khususnya penderita penyakit berat. Selain itu, terkadang tenaga medis tidak hadir, alat, obat, sarana dan prasarana tidak memadai sehingga secara otomatis dirujuk ke faskes lebih tinggi yaitu rumah sakit.

Program kunjungan tenaga medis Puskesmas ke masyarakat dalam kampanye kesehatan dan penanganan dini penyakit sebagai fungsi preventif seharusnya berjalan optimal sehingga mencegah masyarakat datang ke Puskesmas setelah menderita sakit lebih berat. Hal tersebut mempengaruhi kuantitas rujukan peserta JKN-KIS ke rumah sakit. Namun tidak berjalan optimal di Puskesmas Kopo.

Rangkaian masalah tersebut menjadikan penulis tertarik untuk memilih judul "Implementaasi Kebijakan BPJS Kesehatan di Pusat Kesehatan Masyarakat 
Kopo Kecamatan Kutawaringin Kabupaten Bandung”.

\section{TINJAUAN PUSTAKA Kebijakan Publik}

Menurut Nugroho (2014:54) kebijakan publik merupakan keputusan yang diambil oleh negara (khususnya pemerintah) dan strategi untuk mencapai tujuan nasional yang relevan. Kebijakan publik adalah strategi yang dapat membimbing masyarakat pada tahap awal dan memasuki masyarakat dalam transisi periode selanjutnya.

Friedrich dalam Winarno (2012: 20) percaya bahwa kebijakan, sebagai arah tindakan yang diusulkan oleh individu, kelompok atau pemerintah dalam lingkungan tertentu, memberikan hambatan dan peluang untuk digunakan dan mengatasi kebijakan yang diusulkan. tujuan atau mencapai tujuan. Tujuan atau tujuan tertentu.

Berdasarkan beberapa definisi kebijakan publik di atas, dapat disimpulkan bahwa kebijakan publik adalah keputusan pemerintah untuk mengambil tindakan yang berkaitan dengan tujuan yang ingin dicapai guna mewujudkan kepentingan warga negara dan negara.

\section{Implementasi Kebijakan Publik}

Ripley dan Franklin (Winarno, 2012: 148 menunjukkan bahwa implementasi adalah sesuatu yang terjadi setelah berlakunya undang-undang, yang memberikan otorisasi rencana, kebijakan, manfaat, atau keluaran yang nyata. Implementasi Satu Istilah mengacu pada banyak kegiatan yang dilakukan setelah mengikuti pernyataan niat pejabat pemerintah tentang tujuan rencana dan hasil yang diharapkan.

Sementara itu Mazmanian dan Sabatier (Agustino 2008:139) menyatakan implementasi kebijakan sebagai implementasi dari keputusan kebijakan dasar, biasanya dalam bentuk undang-undang, tetapi bisa juga dalam bentuk perintah administratif penting atau keputusan atau keputusan yudisial. Masalah yang akan dipecahkan dengan jelas menyatakan tujuan atau tujuan yang ingin dicapai dan berbagai cara menyusun atau mengatur proses pelaksanaannya.

Dalam proses kebijakan publik implementasi kebijakan merupakan tahap krusial karena merupakan tahap pelaksanaan setelah suatu perundang-undangan ditetapkan supaya menghasilkan dampak terhadap tujuan. Untuk artikel ini, penulis mempergunakan implementasi kebijakan model dari Metter dan Horn.

Model implementasi kebijakan merupakan model implementasi kebijakan top-down yang dikembangkan oleh Metter dan Horn. Model ini merupakan abstraksi dari strategi yang dengan sengaja untuk mencapai kinerja strategi yang tinggi terkait berbagai variabel. Menurut Metter and Horn (Agustino 2008: 142), terdapat 6 (enam) variabel yang mempengaruhi keberhasilan implementasi kebijakan, diantaranya

a. Ukuran dan Tujuan Kebijakan

Jika skala dan tujuan kebijakan realistis di tingkat pelaksana kebijakan, dan skala serta tujuan kebijakan terkait dengan sosial budaya yang ada di tingkat pelaksana kebijakan, maka kinerja implementasi kebijakan dapat diukur. Namun, jika ukuran atau tujuan kebijakan terlalu ideal, atau bahkan utopis, untuk diterapkan di tingkat warga atau komunitas, akan sulit mencapai apa yang bisa dikatakan sebagai kebijakan publik yang berhasil.

b. Sumberdaya

Berhasilnya suatu implementasi kebijakan bergantung pada kemampuan untuk menggunakan SDM yang tersedia, antara lain: SDM yang berkualitas, sumber keuangan, fasilitas dan waktu. sumberdaya manusia merupakan kompenen terpenting sebagai penentu keberhasilan implementasi kebijakan karena manusia yang memiliki kemampuan dengan kualitas yang baik sebagai pelaksana seluruh tahapan prosesnya sesuai ketentuan dari kebijakan yang disahkan.

c. Karakteristik Agen Pelaksana

Keberhasilan suatu kebijakan dipengaruhi oleh karakteristik birokrasi dengan ciri-ciri yang cocok dengan karakteristik dari kebijakan yang akan diimplementasikan. Misalnya kebijakan yang bertujuan untuk mengubah perilaku manusia secara radikal harus ditunjang oleh agen pelaksana berkarakter tegas, baik untuk agen pelaksana dari organisasi formal maupun informal. Namun jika tujuan kebijakan bukan untuk mengubah perilaku manusia 
secara ketat, maka briokrasi yang diturunkan tidak harus berkarakter keras serta tegas, tetapi agen pelaksana yang mampu melakukan strategi pendekatan yang tepat.

d. Sikaap/Kecenderrungan pelaksana

Sikap pelaksana kebijakan akan menentukan keberhasilan kebijakan yang dilaksanakan apabila mengetahui persis masalah yang harus diselesaikan melalui adanya kebijakan. Namun apabila suatu kebijakan dilaksanakan bukan dari hasil perumusan yang melibatkan unsur masyarakat yang memahami tentang masalahnya, Namun kebijakan yang diterapkan bersifat top-down sehingga pengambil keputusan tidak menyadari masalah-masalah yang harus diselesaikan.Oleh karena itu, para pelaksana perlu lebih berupaya agar kebijakan tersebut berhasil dilaksanakan.

e. Komunikaasi Antar Organisasi

Komunikasi akan lancar, jika antara organisai yang terlibat dapat meminimalisir kesalahan yang terjadi. Komunikasi pada tahapan ini lebih ditekankan pada koordinasi anatara pihak yang terlibat dalam proses implementasi karena koordinasi adalah bagian mekanisme yang ampuh dalam mempengaruhi keberhasilan dalam proses implementasi kebijakan. Jika koordinasi dilaksanakan dengan metode komunikasi yang baik, maka kesalahan dalam implementasi akan bisa diminimalisir.

f. Lingkungan Ekosopol (Ekonomi, Sosial dan Politik)

Lingkungan eksternal merupakan penyebab kegagalan dan dapat menjadi pendorong implementasi kebijakan yang efektif. Lingkungan eksternal meliputi lingkungan sosial, ekonomi dan politik. Jika lingkungan tidak ramah, ini mungkin menjadi alasan kebijakan tidak ditegakkan. Oleh karena itu, upaya harus dilakukan dengan mempertimbangkan kondisi lingkungan eksternal yang berkontribusi terhadap pelaksanaan pedoman tersebut. Lingkungan eksternal, termasuk lingkungan ekonomi, sosial dan politik peradilan atau lembaga pemerintah, mempengaruhi sifat sistem pemerintahan, sikap profesional dan keberhasilan implementasi kebijakan.

\section{METODE PENELITIAN}

Penelitian ini menggunakan metode kualitatif dan deskriptif. Menurut Sugino (2012: 8) metode penelitian kualitatif sering disebut sebagai metode penelitian alam karena dilakukan pada kondisi alamiah (natural environment). Metode ini awalnya banyak digunakan dalam studi antropologi budaya dan dikenal juga sebagai metode etnografi. Data yang dikumpulkan dan dianalisis dianggap kualitatif karena sifatnya yang kualitatif.

Informan pada penelitian ini di antaranya: Kepala Puskesmas Kopo, Dokter Gigi Madya, Bidan Penyelia, Perawat Penyelia, Dokter Muda, Dokter Umum, Rekam Medis, Apoteker, dan masyarakat sebagai pengguna layanan kesehatan yang menggunakan kartu BPJS Kesehatan di Puskesmas Kopo.

Penulis mengumpulkan informasi langsung di Puskesmas Kopo, Kecamatan Kutawaringin, Kabupaten Bandung dan dari hasil wawancara kepada informan. Sementara, data sekunder diperoleh melalui: literatur, penelitian terdahulu serta dokumen-dokumen dari Puskesmas Kopo Kecamatan Kutawaringin Kabupaten Bandung.

Teknik pengumpulan data meliputi telaah dokumen, ringkasan, dan wawancara. Metode analisis data yang digunakan dalam penelitian ini adalah Miles and Hoverman Analytical Model (Sugino, 2012: 246): Data Inferiority, Data Validation, dan Data Representation Inference.

\section{HASIL DAN PEMBAHASAN}

Pusat Kesehatan Masyarakat (Puskesmas) berperan dalam penanganan penyakit dan meningkatkan kualitas kesehatan masyarakat sesuai kemampuannya dengan melakukan pengobatan dan penyuluhan kesehatan. Namun, Puskemas memiliki kemampuan yang terbatas dalam membantu pengobatan bagi masyarakat yang sakit. Apabila penyakitnya parah, seseorang tentunya harus diobati di fasilitas kesehatan pada level yang lebih tinggi, yaitu: rumah sakit. Tetapi, ketika ada masyarakat yang sakit mendadak atau mengalami kecelakaan, tidak sedikit masyarakat tidak mampu untuk berobat. Dengan demikian, pemerintah membuat suatu 
program asuransi untuk membantu masyarakat mengurangi bebannya ketika mengalami hal demikian untuk biaya pengobatannya dengan program Badan Penyelenggara Jaminan Sosial (BPJS) Kesehatan.

Dibentuknya Badan Penyelenggara Jaminan Sosial (BPJS) Kesehatan merupakan asuransi yang ditetapkan berdasarkan Perpu Presiden No 12 Tahun 2013 mengenai Jaminan Kesehatan Nasional JKN). Dasar kebijakan tersebut mulai berlakunya JKN sebagai bagian dari SJSN sejak 1 Januari 2014 yang diwajibkan kepada seluruh masyarakat terdaftar sebagai peserta BPJS Kesehatan hingga memiliki kartu sebagai bukti keikutsertaannya untuk membantu beban pembiayaan ketika harus menjalani pengobatannya di Puskesmas atau di Rumah Sakit. Namun, adanya program asuransi tersebut mendapat respon yang beragam dari setiap lapisan masyarakat. BPJS Kesehatan tidak membuat seluruh masyarakat merasa senang dan merasa tenang, sehingga menimbulkan pro dan kontra.

Sebagai landasan kebijakan dari program jaminan kesehatan tersebut pada saat ini adalah Perpres No. 64/2020 tentang Jaminan Kesehatan yang membahas aturan mengenai iuran bagi peserta program BPJS Kesehatan merupakan dasar aturan untuk pelaksanaan pelayanan bagi peserta BPJS Kesehatan yang dilakukan oleh lembaga fasilitas kesehatan yang salah satunya adalah Puskesmas Kopo Kecamatan Kutawaringin Kabupaten Bandung sebagai fasilitas kesehatan tingkat pertama.

Implementasi Kebijakan BPJS Kesehatan di Pusat Kesehatan Masyarakat Kopo Kecamatan Kutawaringin Kabupaten Bandung menggunakan model Metter dan Horn (2008:142). Ini termasuk kebijakan, sumber daya, karakteristik badan eksekutif, sikap / kecenderungan (ukuran) profesional, dan hubungan antara organisasi dan lingkungan ekonomi, sosial dan politiknya.

\section{Ukuran dan Tujuan Kebijakan}

Kebijakan dengan tujuan harus realistis dan terukur akan mempermudah para pelaksana dalam implementasi kebijakan karena dapat mengurangi kesulitan yang dapat menjadi hambatan untuk mencapai tujuan kebijakan. Begitu pula sebaliknya, apabila tujuan kebijakan sulit diukur karena dianggap terlalu berlebihan tentu dapat menemui banyak hambatan dalam implementasinya.

Kebijakan tentang Jaminan Kesehatan dalam bentuk program BPJS Kesehatan tentu sangat membantu masyarakat dalam mengatasi masalah kesehatan, tetapi pada pelaksanaannya memang tidak membuat seluruh masyarakat puas karena kurangnya pemahaman dari masyarakat itu sendiri atau karena kesalahan yang dilakukan oleh pelaksana kebijakan. Salah satu kesalahan yang terjadi di lapangan adalah pendataan terhadap masyarakat yang berhak menjadi peserta PBI dari program tersebut belum sepenuhnya tepat sasaran, yaitu terlihat dari suatu kejadian di Puskesmas Kopo Kecamatan Kutawaringin ada masyarakat kurang mampu yang sakit harus dirujuk ke Rumah Sakit namun belum memiliki kartu BPJS Kesehatan sehingga harus membayar sebagaimana pasien umum dan sudah tentu tidak mampu untuk membayar. Adapun kebijakan dari pihak Rumah Sakit yaitu memberikan kesempatan kepada pihak keluarga pasien mengurus sebagai peserta BPJS Kesehatan untuk bisa mendapatkan layanan jaminan kesehatan dari program tersebut. Namun harusnya kejadian tersebut tidak perlu terjadi apabila tujuan dan sasaran dari kebijakan program BPJS Kesehatan diimplementasikan sebagaimana mestinya karena tujuan utamanya adalah mempermudah masyarakat untuk mendapatkan layanan kesehatan yang layak meskipun kondisinya termasuk kategori kurang mampu.

Saat ini, regulasi tentang BPJS Kesehatan adalah Peraturan BPJS Kesehatan No 3 Thn 2020 tentang Tata Cara Penagihan, Pembayaran dan Pencatatan Iuran Jaminan Kesehatan, dan Pembayaran Denda Akibat Keterlambatan Pembayaran Iuran Jaminan Kesehatan. Selanjutnya Peraturan Presiden Nomor. 64/2020 tentang Perubahan Kedua atas Peraturan Presiden No. 82/2018 tentang Jaminan Kesehatan dan Peraturan Menteri Kesehatan Nomor. 55/2015 tentang Pelayanan Kesehatan pada Jaminan Kesehatan Nasional (JKN) sebagai dasar aturan untuk pelaksanaan pelayanan bagi peserta BPJS Kesehatan.

Terlepas dari kondisi sebagaimana telah ceritakan, Puskesmas Kopo memiliki peran yang penting dalam mencapai kesuksesan dari implementasi kebijakan BPJS 
Kesehatan. Namun ukuran keberhasilannya berbeda dengan pengukuran implementasi secara langsung terkait dengan tujuan dan sasaran kebijakannya karena dalam hal ini peran Puskesmas Kopo merupakan bagian dari pelaksana yang fungsinya memberikan layanan kesehatan dan jenis pelayanan kesehatan yang diberikan meliputi pelayanan rawat jalan hingga pelayanan kesehatan rawat inap. Mengingat hal tersebut, dalam analisis mengenai implementasi kebijakan BPJS Kesehatan di Puskesmas Kopo Kecamatan Kutawaringin Kabupaten Bandung, ukuran dan tujuan program tersebut pada intinya adalah penyediaan fasilitas, Akses pelayanan kesehatan masyarakat di Puskesmas Kopo Kecamatan Kutawaringin Kabupaten Bandung akan menjadi tolak ukur keberhasilan pelaksanaan suatu program kesehatan.

Sebagai Faskes tingkat pertama (non spesialistik), kegiatan pelayanan kesehatan di Puskesmas Kopo sudah cukup efektif dimana Puskesmas Kopo sudah memanfaatkan JKN yang bersifat pelayanan kesehatan perseorangan yaitu secara promotif, preventif, kuratif dan rehabilitatif yang dilaksanakan di dalam dan luar gedung, serta tenaga kesehatan selalu melaksanakan ketentuan yang ada di BPJS Kesehatan agar kegiatannya lancar dan pelaksanaannya berjenjang serta berlanjut sesuai dengan pelayanan kesehatan yang dibutuhkan masyarakat di wilayah kerja Puskesmas Kopo. Selain itu, poster dan leaflet selalu tersedia dan informasi lainnya untuk masyarakat sehingga tidak mengalami kesulitan. Puskesmas Kopo juga patuh dalam membelanjakan dana yang telah diperoleh sesuai dengan kebutuhan puskesmas, seperti adanya pengadaan obat dan BMHP di Puskesmas yang tidak tersedia di Dinas, pihak Puskesmas Kopo membeli sendiri dengan dana BLUD.

\section{Sumberdaya}

Sumberdaya yang memadai disertai dengan kemampuan pengelolaan yang baik menjadi bagian dari faktor yang mempengaruhi keberhasilan implementasi kebijakan. Dengan demikian sumberdaya harus tersedia dan dimanfaatkan dengan baik. Sumberdaya tersebut diantaranya meliputi sumber daya manusia, fasilitas, finansial dan waktu.

Ketika kebijakan memiliki ukuran dan tujuan yang realistis, Namun, semakin sedikit orang yang digunakan pihak berwenang untuk melaksanakan kebijakan akan mempengaruhi penegakan kebijakan dan tidak berjalan mulus. Dengan demikaian sumber daya yang disediakan oleh pembuat keputusan berpengaruh terhadap kelancaran proses kebijakan. Begitu pula ketika sumberdaya finansial dan sumberdaya lainnya tersedia, maka dapat berpengaruh pada terdorongnya ketaatan para pelaksana kebijakan. Implementasi kebijakan BPJS Kesehatan di Puskesmas Kopo Kecamatan Kutawaringin Kabupaten Bandung harus didukung dengan sumber daya yang memadai karena sasaran program tersebut meliputi pelayanan kesehatan langsung kepada masyarakat sebagai peserta BPJS Kesehatan di wilayah kerja Puskesmas Kopo. Dalam hal ini yang merupakan sumberdaya sebagai faktor pendukung keberhasilan implementasi program tersebut dan dianggap sangat penting meliputi sumber SDM dan anggaran. Adapun ketersediaan SDM, prasarana dan ketersediaan dana dalam pelaksaan program jaminan Kesehatan Nasional BPJS Kesehatan di Puskesmas Kopo disesuaikan dengan kebutuhan fasilitas kesehatan tingkat pertama dan tenaga kesehatannya memberikan pelayanan berpedoman pada job desk yang sudah ditentukan. Semua tenaga kesehatan dalam menjalankan tugas pokoknya dilegalkan dengan mempunyai SIK (Surat Ijin Kerja) yang diterbitkan oleh PTSP.

Kemampuan tenaga kesehatan di Puskesmas Kopo sudah cukup sesuai dengan kompetensi yang dipersyaratkan BPJS sehingga mampu menangani kasus-kasus yang menjadi tanggung jawab Faskes Tingkat I, juga dengan adanya Kapitasi yang diperoleh dari BPJS Kesehatan, penggunaannya diperbolehkan sesuai anggaran dan bisa dipakai, misalkan untuk Pelatihan Tenaga Kesehatan, sehingga meningkatkan kemampuan dan kompetensi tenaga kesehatan tersebut.

Dilihat dari penilaian cakupan kinerja, yaitu angka kontrak, rasio rujukan non spesialistik, rasio peserta prolanis terkendali, nilai capaiannya sudah tercukupi. Tenaga kesehatan melaksanakan pelayanan secara efektif sesuai ketentuan dengan memberikan penyuluhan tentang BPJS kepada masyarakat 
Kecamatan Kutawaringin Kabupaten Bandung, tentang kartu BPJS yang ganda / in aktif dan tentang masalah rujukan dengan sistem yang harus berjenjang.

Tenaga kesehatan di Puskesmas kopo juga memberikan penyuluhan kepada pasien dan membantu mensosialisasikan dengan cara yang ramah tentang kartu BPJS yang non aktif sehingga tidak menyebabkan waktu antri yang terlalu lama dan juga puskesmas selalu buka tepat waktu.

Selain keunggulan yang dimiliki oleh tenaga kesehatan di Puskesmas Kopo dari segi kemampuan dan kepatuhannya terhadap tupoksinya namun terdapat kelemahan, yaitu ada kalanya unit kerja di Puskesmas Kopo merasa kewalahan untuk memberikan layanan terbaik kepada pasien, ketika jumlah pasien yang datang untuk berobat sangat banyak namun keberadaan jumlah tenaga kesehatan dan petugas pada bagian loket pendaftaran juga sangat terbatas. Kejadian tersebut sering terjadi pada bagian poli umum dan pasien yang datang mencakup keperluan konsultasi, meminta rujukan, untuk keperluan berobat dan rawat jalan.

Adanya keterbatasan tenaga kesehatan dalam meberikan layanan ketika jumlah pasien yang datang sangat banyak tetap tidak menurunkan kinerja layanan Puskesmas Kopo, karena dengan menghadapi kondisi seperti itu setiap pasien yang datang dengan jenis penyakit apapun selalu terlayani sesuai dengan ketentuan prosedur dan peraturan yang berlaku. Bahkan ketika kondisi penyakit pasien tidak dapat ditangani di Puskesmas seperti komplikasi atau pengdap penyakit kronis dan situasi darutat seperti ibu yang akan melahirkan mengalami pendarahan tentu akan langsung dirujuk ke Rumas Sakit sebagai faskes tingkat dua berikut difasilitasi jika perlu diantar oleh tenaga kesehatan dari Puskesmas Kopo.

Kejadian seperti demikian merupakan gambaran bahwa layanan yang diberikan tenaga kesehatan di Puskesmas Kopo adalah bentuk keseriusan dalam mengimplementasikan tupoksinya sesuai dengan ketentuan kebijakan dalam melayani pasien perserta BPJS Kesehatan.

\section{Karakteristik Agen Pelaksana}

Sifat organisasi bisnis merupakan salah satu faktor yang mempengaruhi keberhasilan penegakan kebijakan. Oleh karena itu, Anda membutuhkan manajer yang memiliki karakteristik yang tepat dan mengikuti pedoman dasar dan tujuan pengukuran. Setelah diidentifikasi, struktur tersebut dapat menggambarkan karakteristik, norma, dan pola hubungan yang terjadi antara kedua aktuator dalam proses implementasi kebijakan.

Puskesmas Kopo Kecamatan Kutawaringin Kabupaten Bandung dalam kontribusinya untuk mensukseskan implementasi kebijakan BPJS Kesehatan sudah seharusnya didukung dengan keberadaan para tenaga kesehatan yang memiliki loyalitas, integritas dan berkomitmen sehingga mampu menerima berbagai konsekuensi dan mampu menghadapi tantangan.

Karakter para pelaksana yang patuh terhadap kebijakan dapat mempermudah terjadinya kesamaan pemahaman dan bisa saling merespon sehingga terjadi kekompakan untuk mencapai tujuan dari implementasi kebijakan secara efektif. Tetapi kenyataannya untuk terjadinya sinergitas dalam implementasi kebijakan memang bukan hal mudah karena banyak unsur yang terlibat dan diperlukan kontrol yang tepat dari pimpinan.

Struktur birokrasi di Puskesmas Kopo dapat menggambarkan karakteristik organisasi melalui mekanisme dan alur tugas sebagai tanggung jawab setiap unsur tenaga kesehatan di Puskesmas Kopo berdasarkan kompetensi dan profesionalisme kerjanya.

Struktur birokrasi, termasuk didalamnya tenaga kesehatan berdasarkan unit kerjanya dan termasuk juga tim verifikasi program. Dalam implementasi kebijakan BPJS Kesehatan di Puskesmas Kopo Kecamatan Kutawaringin Kabupaten Bandung terjadi keharmonisan hubungan kerja antar tenaga kesehatan di Puskesmas Kopo dalam penyelengaraan pelayanan kesehatan bagi peserta BPJS Kesehatan cukup baik. Masingmasing bekerja sesuai tupoksinya dan kegiatan berjalan sesuai ketentuan serta saling membantu dalam menyelenggarakan pelayanan kesehatan bagi peserta BPJS Kesehatan di wilayah kerjanya. Semua bekerja team antara dokter dan tenaga kesehatan lainnya. Keharmonisan ditunjukan juga dengan adanya jasa pelayanan yang diberikan kepada tenaga kesehatan. Pada dasarnya semua pelayanan tidak dibeda-bedakan, kepada pasien umum 
dan BPJS maupun kepada tenaga kesehatan.

Tingkat kepatuhan tenaga kesehatan di Puskesmas Kopo secara umum cukup patuh atas ketentuan yang ditetapkan oleh BPJS Kesehatan dan berusaha untuk tidak merasa terbebani karena ada konsekuensi dan selalu ada monitoring, laporan serta feedback dari BPJS dan dari Dinas Kesehatan. Dilihat dari rasionalisasi pembayaran jaminan kesehatan dan optimalisasi layanan peserta jaminan kesehatan sudah terpenuhi seperti kepatuhan terhadap pemenuhan SIP dokter, dokter gigi dan bidan. Kepatuhan terhadap ketentuan pengelolaan PRB dan kepatuhan dalam melaksanakan ketentuan KBK, namun terdapat juga suatu kekurangan karena berdasarkan ketentuan yang berlaku, setiap tenaga kesehatan seharusnya memiliki STR dan SIP yang menunjang legalitas kinerja tenaga kesehatan dalam melaksanakan tugasnya sesuai dengan ketentuan pada kebijakan BPJS Kesehatan, tapi masih ada tenaga kesehatan di Puskesmas Kopo yang belum mengurus STR dan SIP.

\section{Sikap / Kecenderungan (Disposition) para pelaksana}

Disposition berkontribusi terhadap keberhasilan implementasi kebijakan. Terdapat tiga unsur yang berpengaruh pada kecenderungan pelaksana dalam melaksankan proses implementasi kebijakan, diantaranya Artinya, memahami, menerima, menetralkan, dan menolak kekuatan politik dan reaksi.

Dalam hal ini, pengetahuan dokter merupakan pemahaman tentang tindakan yang mendasari dan tujuan kebijakan yang menentukan pendekatan yang diadopsi Puskmas dan penerapan pedoman BPJS.

Sikap Puskesmas Kopo terhadap kebijakan BPJS mencerminkan dukungan dan ketertarikan untuk melaksanakan program agar dapat lebih melayani masyarakat sebagai Mitra BPJS Keshatan..

Tingkat pemahaman tenaga kesehatan di Puskesmas Kopo tentang kebijakan BPJS Kesehatan cukup baik karena untuk setiap ada regulasi tentang BPJS di informasikan ke petugas walaupun tingkat pemahaman tenaga kesehatan berbeda. Karena kebijakannya dinamis, sehingga pemahamannya kadang masih belum cepat mengikuti, namun dilakukan upaya dengan selalu memberikan informasi yang diulang dalam berbagai kesempatan. Keadaan tersebut tertolong dengan adanya situasi kerja sama yang baik ketika ada kendala di aplikasi p-care yang kadang sedang gangguan / mainternance.

Pemahaman dan kepatuhan tenaga kesehatan dalam mengentry kunjungan sakit dan pasien yang berobat ke Puskesmas Kopo juga cukup baik. Namun jika ada hambatan di aplikasi p-care yang sedang gangguan, pengentryan kunjungan sakit di aplikasi tidak dapat terlaksana.

Secara umum tenaga kesehatan di Puskesmas Kopo cenderung mendukung penuh setiap kebijakan dan program BPJS Kesehatan sejak awal adanya program tersebut hingga sekarang karena terlihat dari keseriusannya dalam menjalankan setiap ketentuan dan aturan menurut regulasi dan kebijakan yang terus berkembang. Mereka selalu intens menanggapi secara positif setiap terjadinya perubahan kebijakan hingga berupaya maksimal untuk memahaminya supaya mampu menjalankannya secara efektif. Netralitasnya juga terlihat ketika melayani pasien sebagai peserta BPJS Kesehatan yang statusnya PBI dengan perlakuan yang sopan dan ramah, memfasilitasi sebagaimana kebutuhannya dan merespon pertanyaan dengan jawaban yang membuat pasien paham.

\section{Komunikasi Antar Organisasi}

Komunikasi dalam bentuk interaksi antara unit atau koordinasi antar instansi dalam menyampaikan tujuan atau maksud yang terkandung dalam kebijakan dimaksudkan agar semua Pihak yang terlibat dalam proses penerapan kebijakan dapat memahami konten yang dikirimkan baik secara langsung maupun melalui alat komunikasi.

Kepatuhan terhadap penyelenggaraan BPJS kesehatan merupakan desain atau keberlanjutan Puskesmas. Kompatibilitas yang diterapkan di Puskesmas di Kabupaten Bandung kini sudah memenuhi syarat.

Sosialisasi dapat dilakukan Kantor BPJS dapat dikatakan cukup baik, yaitu adanya sosialisasi melalui website dalam menerangkan dan menjelaskan program, mekanisme serta prosedur BPJS Kesehatan dan informasinya juga terus diperbaharui. Namun tidak semua kalangan masyarakat mampu mengakses informasi melalui internet karena tingkat 
pendidikan dan tingkat pemahaman akan teknologinya tidak sama. Dengan demikian, adanya upaya dari tenaga kesehatan di Puskesmas Kopo Kecamatan Kutawaringin Kabupaten Bandung dalam melakukan sosialisasi kepada masyarakat di wilayah kerjanya tentu sangat membantu keberhasilan implementasi kebijakan BPJS Kesehatan.

Sebelum melakukan sosialisasi, tenaga kesehatan di Puskesmas Kopo telah mendapatkan pelatihan sehingga siap untuk mensosialisasikan program BPJS kepada masyarakat khususnya di wilayah kerjanya bekerja sama dengan bidan, kader kesehatan Posyandu, pada masyarakat yang belum terdaftar sebagai peserta BPJS Kesehatan. Tetapi meskipun demikian hasil sosialisasi belum tercapai secara optimal karena pelaksanaannya ternyata pada kegiatan rutin yang sudah terjadwal seperti kegiatan diawal setiap bulan berupa imunisasi bayi dan balita berikut pemeriksaan ibu hamil.

Berkaitan dengan job desk Nakes Puskesmas Kopo bukan hanya merangkap untuk melakukan sosialisasi pada kegiatan yang sudah terjadwal misalnya di posyandu, tetapi lebih daripada itu, yaitu tenaga kesehatan juga perlu memberikan pemahaman kepada kelompok masyarakat yang menjadi sasaran yang tepat terkait prosedur pelayanan di Puskesmas dengan melibatkan perangkat desa sebagai dukungannya terhadap peningkatan kesehatan masyarakat. Kegiatan tersebut sangat bernilai positif untuk masyarakat supaya bisa memahami prosedur pelayanan kesehatan terutama tentang layanan yang berkaitan dengan program BPJS Kesehatan.

Komunikasi yang dilakukan dengan metode yang baik oleh para pelaksana kebijakan seperti oleh tenaga kesehatan di Puskesmas Kopo dapat mendorong masyarakat untuk menyadari pentingnya JKN (BPJS) karena dengan kepesertaannya masyarakat bisa mendapatkan banyak manfaat dalam layanan kesehatan untuk meningkatkan derajat kesehatannya karena ada kalanya kondisi kesehatan akan melemah atau didera suatu penyakit yang tidak terprediksi sehingga mengharuskannya menjalani pengobatan namun dalam kondisi keuangan yang minim, maka disaat itu akan terasa manfaatnya terdaftar sebagai peserta BPJS Kesehatan.

\section{Lingkungan Ekosopol (Ekonomi, Sosial dan Politik}

Lingkungan eksternal niscaya akan berkontribusi pada keberhasilan implementasi kebijakan. Lingkungan eksternal meliputi lingkungan ekonomi, sosial dan politik. Namun jika kondisi yang tidak mendukung pasti menjadi penyebab gagalnya implementasi kebijakan, oleh karena itu keberhasilan implementasi kebijakan tersebut membutuhkan dukungan dari kondisi eksternal yang kondusif.

Suatu ketentuan atau pedoman yang bertujuan untuk memenuhi kebutuhan mendasar masyarakat dan dianggap sebagai permasalahan utama bagi masyarakat tentu menghasilkan dampak sosial, yaitu membangun gairah masyarakat dalam menerima kebijakan tersebut untuk diimplementasikan.

Tujuan yang mendasari program kebijakan BPJS Kesehatan ini menunjukkan keberpihakan terhadap masyarakat khususnya sangat menguntungkan bagi masyarakat tidak mampu dalam berobat, sehingga kebijakan tersebut dapat diterima luas oleh masyarakat. Kecenderungan tersebut tentunya sangat berkaitan dengan proses implementasinya. Dengan demikian diperlukan sikap yang konsisten dari para pelaksana khususnya tenaga Kesehatan di Puskesmas Kopo untuk melaksanakan program sesuai dengan tujuan kebijakan BPJS Kesehatan serta sesuai visi dan misi Puskesmas Kopo sehingga akan mampu meminimalisir masalah-masalah yang timbul baik masalah yang bersifat politis ataupun masalah personal masyarakat yang dapat menghambat implementasi kebijakan.

Masyarakat di wilayah kerja Puskesmas Kopo dilihat dari aspek sosial ternyata memiliki tingkat kepeduliaan yang tinggi terhadap keberlangsungan program BPJS Kesehatan karena merasa bahwa adanya program tersebut terasa membantu meningkatkan taraf kesehatan masyarakat. Dengan adanya program BPJS Kesehatan, profesi masyarakat di wilayah kerja Puskesmas Kopo Kecamatan Kutawaringin sebagai petani, buruh, pengusaha dan kalangan pegawai pemerintah dan swasta mampu merasakan manfaat yang sama dalam layanan kesehatan. Namun keadaan ekonomi yang tidak stabil atau 
bahkan ketika melemah tentu dapat mengubah tingkat partisipasinya apabila terdaftar sebagai peserta non PBI karena harus membayar iuran dan selain itu, situasi politik juga berperan dalam memberikan pengaruh bagi tingkat partisipasi masyarakat di wilayah kerja Puskesmas Kopo terhadap program BPJS Kesehatan karena situasi politik yang tidak stabil menimbulkan keresahan bagi masyarakat seperti terancamnya keamanan lingkungan, terancamnya kegiatan bisnis dan profesi mereka.

Saat ini masyarakat pada umumnya dan masyarakat di wilayah kerja Puskesmas Kopo khusunya berharap BPJS Kesehatan terus menjadi program yang diprioritaskan oleh pemerintah dalam memenuhi hak masyarakat atas hidup sehat, sehingga keberadaan masyarakat yang kurang mampu bisa mendapat pelayanan kesehatan yang dibutuhkan sebagai peserta BPJS Kesehatan dengan status Penerima Bantuan Iuran dapat juga merasakan dampak dengan adanya program BPJS Kesehatan dalam meningkatkan kesehatan masyarakat.

\section{SIMPULAN}

Implementasi Kebijakan BPJS

Kesehatan di Pusat Kesehatan Masyarakat Kopo Kecamatan Kutawaringin Kabupaten Bandung, sebagai berikut :

1. Ukuran dan Tujuan Kebijakan

Jaminan Kesehatan Nasional dalam bentuk program BPJS Kesehatan membantu masyarakat dalam mengatasi masalah kesehatan, tetapi pada pelaksanaannya tidak seluruh masyarakat puas karena kurangnya pemahaman dari masyarakat atau karena kesalahan yang dilakukan oleh pelaksana kebijakan. Salah satu kesalahan yang terjadi di lapangan adalah pendataan terhadap masyarakat yang berhak menjadi peserta PBI dari program tersebut belum sepenuhnya tepat sasaran.

2. Sumberdaya

Kemampuan tenaga kesehatan di Puskesmas Kopo sudah cukup sesuai dengan kompetensi yang dipersyaratkan BPJS sehingga mampu menangani kasuskasus yang menjadi tanggung jawab Faskes Tingkat I.
3. Karakteristik Agen Pelaksana

Karakter para pelaksana yang patuh terhadap kebijakan dapat mempermudah terjadinya kesamaan pemahaman dan bisa saling merespon sehingga terjadi kekompakan untuk mencapai tujuan dari implementasi kebijakan secara efektif. Tetapi kenyataannya untuk terjadinya sinergitas dalam implementasi kebijakan memang bukan hal mudah karena banyak unsur yang terlibat dan diperlukan kontrol yang tepat dari pimpinan.

4. Sikap / Kecenderungan (Disposition) para pelaksana

Sikap tenaga kesehatan di Puskesmas Kopo pada BPJS Kesehatan sudah memberikan dukungan dalam melaksanakan program secara lebih baik dalam melayani dan memenuhi kesehatan masyarakat sebagai peserta BPJS Kesehatan.

5. Komunikasi Antar Organisasi

Sosialisasi yang dilakukan oleh Kantor BPJS dapat dikatakan cukup baik, yaitu adanya sosialisasi melalui website dalam menerangkan dan menjelaskan program, mekanisme serta prosedur BPJS Kesehatan dan informasinya juga terus diperbaharui. Namun tidak semua kalangan masyarakat mampu mengakses informasi melalui internet karena tingkat pendidikan dan tingkat pemahaman akan teknologinya tidak sama.

6. Lingkungan Ekosopol

Masyarakat dalam area kerja Puskesmas Kopo dilihat dari aspek sosial ternyata memiliki tingkat kepeduliaan yang tinggi terhadap keberlangsungan program BPJS Kesehatan karena merasa bahwa adanya program tersebut terasa membantu meningkatkan taraf kesehatan masyarakat. Dengan adanya program BPJS Kesehatan, profesi masyarakat di wilayah kerja Puskesmas Kopo Kecamatan Kutawaringin sebagai petani, buruh, pengusaha dan kalangan pegawai pemerintah dan swasta mampu merasakan manfaat yang sama dalam layanan kesehatan.

Implementasi kebijakan BPJS Kesehatan di Puskesmas Kopo Kecamatan Kutawaringin Kabupaten Bandung masih terdapat kendala yang ditemukan dalam pelaksanaan yaitu pendataan terhadap masyarakat yang berhak menjadi peserta PBI 
belum sepenuhnya tepat sasaran, adanya keterbatasan tenaga kesehatan dalam meberikan layanan dan masih ada tenaga kesehatan di Puskesmas Kopo yang belum mengurus STR dan SIP.

\section{DAFTAR PUSTAKA}

Agustinno, (2008). Dassar-dasar Kebijakan Publik. Banddung: Alfabeta.

Akiib, Haeidar dan Antonius Tariggan. (2008). "Artikulasii Konsesp Implementasi Kebijakan: Perspektif, Model dan KriteriaPengukurannya,” Jurnal Baca, Volume 1 Agustus 2008, Universitas Pepabari Makassar, hlm 1.

AsihEka Putri, 2014, Seri Buku Saku-2: Pahaam BPJS (Badan Penyelenggara Jaminan Sosial Kesehatan), iedrichEbert-Stiftung, hlm.7.

Nugrooho, Taufan.,dkk, KebijakanPublikFormulasi, Implement asi danEvaluasi. Jakarta: Gramedia.

Subarsono, 2013. Analisis Kebijakan Publik Konsep Teori dan Aplikasi. Yogyakarta: Pustaka Pelajar.

Sugiyonno, (2012). MetodePenelitian Kuantitaf Kualitatifdan $R \& D$. Bandung: Alfabeta.

Winarno, (2012). Kebijakan Publik. Yogyakarta: Penerbit CAPS.

\section{Peraturan Perundang-Undangan}

Undang-Undang Dasar (UUD) Tahun 1945.

Undang-Undang (UU) Nomor 40 Tahun 2004 Tentang Sistem Jaminan Sosial Nasional.

Undang-Undang (UU) Nomor 24 Tahun 2011 tentang Badan Penyelenggara Jaminan Sosial.

Peraturan Presiden (Perpu) Republik Indonesia Nomor 64 Tahun 2020 Tentang Perubahan Kedua Atas Peraturan Presiden Nomor 82 Tahun 2018 Tentang Jaminan Kesehatan.

\section{Sumber Lain}

https://www.beritasatu.com/irawati-diahastuti/kesehatan/557047/sistemkapitasi-puskesmas-perlu-dikaji-ulang

https://www.medcom.id/nasional/peristiwa/0k8 g62Pb-masalah-bpjs-kesehatan-ada-dikualitas-puskesmas https://tirto.id/fungsi-pengobatan-puskesmasdisebut-bikin-defisti-bpjs-makindalam-ehZg 